\title{
The Legal Order And İts Relation With The Power And The Economy İn The Current Brazilian Scenery, Instrumentality a priori And Rationality a posteriori
}

\author{
Bruno Augusto Sampaio Fuga \\ Postgraduate in Civil Procedure. Postgraduate in Legal and Political \\ Philosophy. Master in Law. Lawyer and teacher
}

doi: 10.19044/esj.2016.v12n4p406 URL:http://dx.doi.org/10.19044/esj.2016.v12n4p406

\begin{abstract}
The Brazilian Legal system and its relation with the power in the current Brazilian scenery, and also the use of a posteriori rationality of the judge and the priori instrumentality of the legislator and of the Executive, is the theme of the present study. Its goal is to show a brief historical evolution of the Law and the State, the Power aspects, the forms of State and its acting with the origin of population. The next step is to present the use of Brazilian Legal System as a form of organization, that is, a priori instrumentality and the evolution from Liberal State to Social State, with significant changes in the legal aspects and in its form of acting. Furthermore, we carry on with the world crisis, especially the one of 1929, whose changes imposed by the end of Second World War (the decline of legal positivism) and also the advances which came with the globalization in 1990. Still considering crisis, it is discussed about the 2008 crisis and its consequences, the European crisis with its high costs of a Social State. A parallelism was done between the economy and the Law and besides that, it was drawn a legal scenery after these evolutions. Regarding these relations of power and the crisis of the power tripartism, we also showed that an ascension of Legal Law can be named as the legal protagonist or, for some, legal activism. These role has some reflexes in the Judicial Discretion, in the active management of processes, in the legal inflation of the Legislative and Executive (provisional measures), in the use of process as a strategy of power, in the legalization of politics and in the creation of binding overviews. Some case studies and considerations about justice were showed. This research is justified because the power, the contemporary legal scenery, the judicial role, the economy and the Law, and the forms of acting of the State (Liberal and Social) are current themes in the study of operators and Law scholars. Thus as these inquiries show great influence in the democratic state of Law.
\end{abstract}


Keywords: Processing Adequate technique, a priori instrumentality, a posteriori rationality

\section{Introdution}

An important question to an expert in civil is to know which procedural technique is straightly connected to the effectiveness; thus, study or try to know which the adequate procedural technique is of great importance. It is said that procedural technique in a dual sense: limits of discretion, deadlines, given powers to judges, procedural flexibility, opened norms of character, process, procedures and related topics.

The study of adequate procedural technique and the limits of discretion power are proposed and are going to be studied here. This theme is believed to be the pillar to the construction of the civil process (silly mistake).

With the studies of Nelson Nery Junior (2010) and Kazuo Watanabe (2012) we identified that the crisis of the process is not only about the process (positive system). It is the whole structure, the professional search, physical structure, the great quantity of actions, and, mainly, the State as a big litigant, that is, the one that should look for the solution in thesis. This is the greatest litigant.

It was identified that the problem of the process is not the process itself, but the power. About this theme, we remember the lecture in Brazil of professor Marinomi ${ }^{75}$ about the new CPC, claiming that the problem is not the process code, the letter of the law, the problem would be more complex. It was easy to identify that the central question is not the letter of law, it is not written and printed in a code, the origin of the crisis in other thing.

We identified a process used with power strategies as background, but not only one process, that is, a Law used as power strategy. It was then in Foucault that we found some bases to affirm that the power is diffuse, so it is not possible for the State to get this request in order to impose certain interests. Finally, the theme was created.

Studies and studies to identify that in the legal order, not only in it, but in the State as a whole, there is an instrumentality a priori and a rationality a posteriori ${ }^{76}$. Baring this scene in mind, the theme was finally delimitated.

\footnotetext{
${ }^{75}$ Procedural Congresso Right - Chalenges of the New Civil and Penal. 2010, Curitiba/Pr.

${ }^{76}$ It is necessary in this moment to adopt a semantic pact in the presente article. Futher, we will talk about the term $a$ priori and $a$ posteriori with the content and the purpose described in the article. However, when we refere to these terms, we will be referring to the legal order and, mainly, to the content written in the end of the article. These references will not connect to the theory of the knowledge, empirism or related issues, so we limited to our central
} 
There is a creation of law, which is not pure just with discussions of justice in metaphysics. There is a game of power, interests, great groups, ethical and economical discussions and others topics. The lawmaker has a desired mean in the edition of the law and, in order to do that, we determined the instrumentality a priori. This instrumentality can be straightly connected to the power that is diffuse. This is the hypothesis we will analyze in the present study.

There is also the rationality a posteriori that would be the movement of the sentence or legal decisions to adequate some of the intended purposes. This means that because of interpretations, open character rules and discretion, the judge can suffer influence of the power that is diffused and, so, suit the legal custody to certain purposes and this could be of macro-justice, economical purposes, media content and so on.

Within this scenery we identified that the economy has a fundamental role in the aspects of power and also of the Law. Sometimes even in thin lines. The world crisis described before, built our ways of acting, legislate and judge. The 1929 crisis demonstrates the end of classical liberalism, with the worry to guarantee the fundamental laws by the judges, with greater participation of the government in the economy. The period of 1945, post War, is characterized by principle and logical opening and the need to use a jurisprudence of values by the judges. In the world crisis of 2008, the lack of rules of market and the end of State Neutrality is clear, that is, a bigger need of having the State intervention in the economical domain. The European crisis is the social welfare with its high costs being important laws which are compatible with the new situation and also judged in this sense (later this question will be deeper analyzed)

Still having in mind the contemporary context it is easy to note that there is judicial prominence, a reflex of this game of power. As the plan is more pragmatic, we intend to show some decisions of pragmatic cases to identify the eventual activism and mainly, some traces of rationality $a$ posteriori. With this game of power and its influences, which will be identified by the reader during this reading, it is impossible not to think in what justice is. Not in a metaphysic or philosophical plan, but with this scenery, in pragmatic view, what has been done in order to have justice?

It is pointed out that the problematic formulation of the present thesis is seen as we questioned if there is an instrumentality a priori and one rationality a posteriori in the current legal order and, with the concrete case analysis, how would this manifest? Other problematic is the relation of power with the legal order. Is there a pure and suitable procedural technique

problem and our theme. The present article is also a summary of a book to be published in 2015 by the same author. 
in the order to make a better solution of the conflicts and if there is not, what is the motive of its no existence?

This study is justified because the theme is recurring in legal context and with great influence in this specific legal process and access to justice, institutes which are of very big importance in the Law and the structure of the State.

We had, since the beginning, as our goal, to verify the influence, the existence or not of the suitable procedural technique in the specific legal process and also the reflexes of power in this system. Therefore, we researched, the Law, the Power, the Economy, the world Crisis and the reflexes of the judicial prominence. Besides that, we investigated some considerations about justice and the study of cases due to these questions.

The methodology used was the hypothetical-deductive one because it begins raising and analyzing the problems presented in order to reach the hypothesis. Thus, we follow with the study of this article and in the sequence; we will discuss the Law and the power in relation to the complementarity. We highlighted that except the book of Hart and Dworkin which we used for the research written in English, the rest are books with Brazilian experts and, however, written in Portuguese. Then, the translation is ours. So, follow the research.

\section{Law And Power}

The Law has clear relation with the power: the Law without power is helpless, and the power deprived of legal reference converts in pure force or choice $^{77}$. The power is also an inseparable attribute of human life and consequently, of the Law. The power produces social changes of the social dynamic, reasons which we dedicate particular attention to the theme.

A significant advance in the historical evolution to show the outlines of a modern world would turn up. It was the end of the feudalism ${ }^{1}$, so the rules for the development of the society begin. Furthermore, we also have here the end of the monarchy and the imposition of the limits of royal power. Because of this change, the law becomes necessary as an instrument of power to organization.

The techniques of power appear with the birth of the population around the XVI century. This means that is not only the individual who worries the State, but the population as a whole.

The rationality through the legality comes in this context of the end of orders imposed by a supposed divine power and the appearance of the

\footnotetext{
${ }^{77}$ REALE, Miguel. Pluralismo e liberdade. 2. ed. Rio de Janeiro. Expressão e Cultura. 1998, p. 230.
} 
cities. The Law starts to be a necessary procedure to governability. In this context, we also have legal codifications and the appearance of the Constitutions themselves.

The population is dominated through the legality, through Law. Mainly after the French Revolution because the legal interpretation of the law was prohibited. Then, a vertical system of power is present having the law in the top of the pyramid.

We entered, therefore, in a period that the legal positive system cannot tutor and give the legitimacy for the actions of the State. To Foucault $^{78}$ it is necessary to free ourselves of the power-law, powersovereignty image and, also to remember the power is diffuse.

Ferdinand Lassalle (1933) points out that the Constitution is the addition of real factors of power and that in this scenario the role of economy is essential in the government. He continues, saying that the truth is formed by several coercions and that the Law itself is formed by great influence of this power.

Some scholars say that the Law has a strong influence of politics. It is almost an absolute politicization, others, softly, say that it has only a strong influence ${ }^{79}$. It is unquestionable, then, that the power is not something unitary or absolute, it is diffuse ${ }^{80}$, multifaceted ${ }^{81}$, it is something that circles $^{82}$.

So, in this way, it is necessary to study which of these are reflexes of power, which is the historical evolution of this context and which are the main influences of our legal order and contemporary world.

\section{World crisis}

The study of the world crisis is of great importance because they contributed to form the current structure of the world context, so as any crisis of today's world it would influence the future. The one of 1929, for example, is the crisis of the classical liberalism and, with it we have the end of wild

\footnotetext{
${ }^{78}$ FOUCAULT, Michel. História da sexualidade I: A vontade de saber. Tradução de Maria Thereza da Costa Albuquerquer e J. A. Guilhon Alburqueque. 1 ed.. São Paulo, Paz e Terra, 2014, p. 99 Do original Francês: Histoire de la Sexualité I: La volonté de savoir.

${ }^{79}$ GUERRA FILHO, Willis Santiago. Teoria política do direito: a expansão política do direito. Willis Santiago Guerra Filho, Henrique Garbellini Carnio. 2 ed., rev., atual. e ampliada. São Paulo/; Editora Revista dos Tribunais, 2013, p. 111

${ }^{80}$ FOUCAULT, Michel. Microfísica do Poder. 28 ed. Rio de Janeiro: Paz e Terra, 2014a, p. 15.

${ }^{81}$ NUNES, Dierle. Direito Jurisprudencial. Precedentes, Padronização decisória preventiva e coletivização. Teresa Arruda Alvim Wambier coordenação. São Paulo. Editora Revista do Tribunais, 2012, p. 260.

${ }^{82}$ FOUCAULT, Michel. Microfísica do Poder. 28 ed. Rio de Janeiro: Paz e Terra, 2014a, p. 285.
} 
capitalism. The basis for the Interventionist State is the reason of governmental actions implemented in the United States after this period. The State starts to participate of the Govern in the economy and to have other functions. With this opening, the Court starts to use the New Human Rights.

The crisis or the post-War of 1945 is characterized by the decline of classic positivism. After the great catastrophe the moral implication are rethought and mainly in the words jus, recht, diritto or droit ${ }^{83}$. In this time, all the legal patterns broke down, so it is necessary to rethink about them ${ }^{84}$. Significant alterations in the legal order appear in Germany, for example, with a wide system of fundamental Laws and the centrality in the dignity of the human person, the States starts to be the biggest agent of attendance of the needs of all the population.

The crisis of 2008 was the biggest crisis since the depression of 1929 (collapse of the New York Stock Market). It started by the lack of regulations of the financial market, then it was evident that this was dangerous. Moreover, it brings a supranational characteristic and the reflexes of the positive and negative aspects of intervention of the State in the economic domain.

The European crisis, on the other hand, is the Social Crisis of the State. The present State after the 1929, 1945, 2008 crises, mainly in public politics, collapses (social welfare crisis). This state has high costs so therefore, they are unsustainable.

Important changes in the form of State are clearly noted and, consequently, in the way of acting of the legal order because it must follow the social framework. We had a crisis of Liberal State, after a crisis of the positive system and then, a crisis of the Non-interventionist State in the economy. Recently, we are having, In Europe, the crisis of the Social State.

The pure Liberal State, which today we can ascertain, is not possible, so as a positivism system without values or a Social State because its high costs are high.

With the crises we can understand their reflexes and comprehend the current world scenery. We have a social State, but it is worried with the economical balance (at least it should be) and there is no classical liberalism, so, there are still liberal characteristics. Finally, we do not adopt a positivism

\footnotetext{
${ }^{83}$ HART, Herbert Lionel Adolphus. O conceito de direito. Organizado por Penelope A. Bulloch e Joseph Raz. Tradução de Antonio de Oliveira Sette-Câmara. Revisão de tradução: Marcelo Brandão Cipolla. Revisão técnica Luiz Vergílio Dalla-Rossa. São Paulo: Martins Fontes, 2009, p. 269. (Biblioteca Jurídica WMF).

${ }^{84}$ ARENDT, Hannah. Responsabilidade e julgamento. Edição Jerome Kohn. Revisão técnica Bethânia Assy e André Duarte. Tradução Rosaura Einchenberg. São Paulo: Companhia das Letras, 2004, p. 118.
} 
without the use of principles, values and interpretations, all these institutes are present in our legal order, and really present.

\section{Law, Economy And World Scenery}

The link of Law with the economy is notorious and its study is of great importance. The economies studies the usage of scarce resources in order to obtain the best possible result ${ }^{85}$. The Law, not differently, tries to tutor the organization of these scarce assets, give orders, impose custody and the sanction due to the legal infractions.

There are scholars who claim that the Law is a mere reflex of the economical movement. Godoy (2014), about the theme and in the beginning of his article points out while the infrastructure of the economy determine the niches of the super-structure, the Law will be a mere reflex of economical movement.

The Law, for example, is necessary in a legal system to adequate the market, the business, competitive and financing forms of organization, the taxable system and related institutions. The Law has the purpose of giving security and predictability to the business and the mission (or at least it should have) of identifying the most efficient legal norm from the economical point of view.

The life from the moment we interfere in the natural Laws, as Faria (2012) points out, can be modified: how it is to how it should be. There is the possibility of an interventionist State, with legal basis, choose which are the necessary economical aims within the society. This field is clearly connected to the purposes of Justice.

The economy is an important factor and the Law, is in this sense, has also an important role to reach this purposes, so, the difficulty appears when we demonstrate that as bigger the decision-making power of the economist is, smaller is the legal certain, that is what the judges answer facing the consequences of an economical reason. The theme, therefore, has complex questions.

We do not adopt a reductionist view of the Law to the economy. The Law has and must have a great worry with economical purposes, but not a narrow economical view. On the other hand, it is dangerous, very dangerous because the Law cannot be unconcerned of the economical aims.

In a State of Social State crises (European crisis), for example, the legal order cannot in its instrumentality priori continues to produce norms which elevate the social expenses and its inherent expenditures. Thus, as the rationality a posteriori cannot keep precedents, which raise the public costs,

\footnotetext{
${ }^{85}$ SOUZA, Nali de Jesus de. Economia básica. 1. ed. 8 reimpr. São Paulo: Atlas, 2014, p.
} 12. 
it is a clear need of rationalization in the new social context. Therefore, the Law must follow these changes.

The instrumentality a priori is, unquestionably, important because it is an instrument of social transformation, so we see the clear relation with the economy. The Law is not, hence, something just to harmonize conflicts and the legitimacy of power because it has a fundamental role in the implementation of public politics both in its instrumentality a priori and in its rationality a posteriori.

The critic, is however, well present in this scenario, and the Law has only the function longa manus of political and social intervention. It means that, in spite of the fact that the Law glimpses the benefits of its connection with the economy, verify that this connection can be better used with public strategies, strategies of governability (presence that, in our point of view, is really important for the Brazilian Government)

The economical factor can still be, in the presented critic, used for strategic purposes of power, both in the instrumentality a priori and in the rationality a posteriori, a fact that justifies the current crisis of the Legal System. The danger of the crisis is the legal rationality to be defined not $a$ priori, but only a posteriori.

\section{Legal prominence and considerations about justice}

The prominence of the legal system is also the result of historical evolution and it is well present when we write about the world crises. In order to guarantee the fundamental rights it is necessary to widen the use of principles and values in society, mainly after the Second War, beginning, in this way, the frameworks of this current scenario.

It is the judge, however, a protagonist of one democratic revolution of justice and, so, he becomes an important character for the economical frames and public politics. This behavior is verified mainly after the Constitution of 1988 in Brazil. It is highlighted that even after its application there was a period of legal pacifism, which came to change this outline with the course of time and the change of ministers. Brazil does not have a revolution like Germany, but it has an evolution.

The discussion is latent and after long years of pacifism, the prominence rises, with some discussions, some are fervent by the unrestricted defense of powers for the legal system. In our point of view, they are really dangerous. As the neutrality is dangerous because it makes the legislator a superpower, the unrestricted prominence is also dangerous because it makes the legal system also a superpower, which could be used as a power strategy in its versions of rationality a posteriori. 
A politicized jurisdiction shares the responsibility by the use of violence and transforms the judge into righteous, makes the justice politicized approaching it to the marketing of opinions.

It is necessary, in our opinion, a study of the adequate procedure, but not putting apart the use of values, principles because as Dworkin said, the sovereign makes use of the good fame of Laws to impose their interests. To avoid this, however, it is necessary to do a substantial process, a judge with powers but not unrestricted, or a Hercules judge because only in the mythology, the Messianism does not exist.

In this scenario of the legal prominence, some branches, which we separated for analysis, appear and they are consequences, and however, it is necessary to analyze them.

First, we will analyze the legal discretion and the norms with open clauses. Hart and Dworkin and Hart contributed a lot for this discussion because the first one affirmed that the judge should in difficult cases judge with legal discretion and the second one claimed not to be possible because the judge should value themselves in these cases of principles. Although with divergent opinion, both accept the possibility of the interpretation of the norm and agree with the existence of open clause norms (each one with their peculiarities ${ }^{86}$ ) It is important to point out that in the current framework there is not any closed system, without possibilities to interpretation.

The interpretation is important to avoid a system, ironically it seems, it is unfair. It is the legal system function to protect the natural Laws $^{1}$ or avoid that tyrants benefit of the good fame of the law to locate their interests. The possibility of a system open to the application of principles is however, essential to any scenario of justice. We protect, though our worry with unrestricted powers, the legal restricted activism, the one which must be beat because it will be as evil as the positivism in its classical form.

To sum up as Eros Grau (2011) points out, the existing Law (presumed Law) and the supposing Law, which probably exists, (codified Law) of society. These both Laws must be respected. We already affirmed that with a simple logic, we will not reach the truth; this error of positivism should be put away.

The active management of process was also a support for the legal prominence. We only question the implications of the active management of a process by the judge's side because it demands bigger expenses and productivity by the magistrate's side, this who in the procedural relation is

\footnotetext{
${ }^{86}$ For more details, I indicate the book Comtemporary Law - Perspectives. Article Law and Discretion. The Discretion of the Judge: discussion between Dworkin and Hart. Bruno Augusto Sampaio Fuga Elve Miguel Cenci. Editora CRV, 2013:47/75
} 
the one who has less knowledge about the case compared with the author and the defendant. The procedural system of Portugal allows the flexibility (principle of formal adequacy), the English procedural system which gives powers to the judges and then, it is possible to avoid empty formalities to certain cases, or the French procedural system which allows the antiactualization of the justice, of the process and of the ways of regulations of litigants.

Other highlighted theme is the legislative Law. The more the legislator or the State creates norms, ironically, bigger is the possibility of discretion by the judge. In our view, this is related to the microphysics of power, with the open character, with the own language and with power. The State should not, however support itself totally in an instrumentality a priori for their purposes.

The more complex the legal system, the more ineffective it will be. We verify that in economic issues, the State tries to impose determined instrumentality to fulfill their purposes, so this instrumentality can suffer a rationality a posteriori. The legislative inflation can still be the result of the relations of power that exist in society, that means, the created laws to fulfill some determined interests, factor which enhances the emptiness of the legal system in some aspects.

To Faria, the contradiction is present in the moment in which as more the State legislates the more it accelerates the emptiness of its own Law functionality in a way that the legal system is confused to the political system. The legal prominence and the discretion created is also, a result of this legislating anger.

The process in this framework can be a strategy of power. It can be both in its instrumentality a priori or in its rationality a posteriori. The norm, which tries to interfere in the social-economical order, for example, is the strategy of power and also the edited norm to fulfill determined purposes or institutions. The existing Law (presumed Law) is an instrument of class dominance and after that the legitimacy is demystified.

Dworkin when talking about this theme already mentioned the need of reconstruction of the Law because of the legal decision is not complete due to the vicissitude of politic and to the amalgam of reasons of the Law legitimacy.

The process as a power strategy can start the same vicious circle of the legal inflation because it can imply more discretionary power and with that, its interpretation. The norm as a power strategy can be questioned by the legal system, being, however, present in the strands of the crisis of the legal system.

The political legislation is the acting of the legal system in themes in which should be discussed in the political scope. This system does not 
choose theses pleadings it is stimulated for the trial, not having, in these cases to start, a gesture of activism. The critic is that the Law should not have this link with the politics, it cannot try to support the masses, to be populist, that means it should not do what a politician does because we could have an inversion of a dangerous role.

It is true that we count with innumerous precedents in this situations of the Supreme performed, in our point of view, certain. It did what it should be done against the other power inertia. It is not a movement, which should be simply encouraged, it is not a simple solution to the current crisis.

The legal system is not prepared to answer the economical questions. Streck $^{87}$, for example, points out that in São Paulo, the expenses of the State Board of Health with medicine which were condemned legally in 2011 reached R\$ 515 million, almost RS 90 million spent above the foreseen budget of the year which were invested in medicines. The indoctrinator highlights that the politicization is not a harm itself but the problem is the activism.

The binding precedent is the example of the process as strategy of power in its clear instrumentality a priori. Although it is necessary in the world context and in determined pleadings, the legal decision that has a concrete character and it becomes abstract, making the judge interpret their own decision.

The last point about the legal prominence is the State as a great litigant. The State is responsible for nearly 60\% of the current processes (NERY JUNIOR, 2010). It has, however, interest in the instrumentality $a$ priori and in the rationality a posteriori too. The legislator is evil and the great litigant.

The great quantity of disputes implies into economic problems, lack of investments, high costs, insecurity; ironically, who should be the most important fighter is the biggest encourager. The delay in the trial in many situations is good to the State, and the scenery is dangerous because if this is the case, we will observe an absence of interest or even though an inertia for fast alterations.

\section{Cases Study In Brazil}

A great initial intention of separating some cases of huge repercussion is to make the rationality a posteriori evident in written form to support some specific interest of power, sometimes State politics, other times Government Politics, but this is not an easy task.

\footnotetext{
${ }^{87}$ STRECK, Lenio Luiz. O ativismo e a judicialização: De como os números podem velar o fenômeno. In Novo Constitucionalismo Latino - Americano. O debate sobre novos sistemas de justiça, ativismo judicial e formação de juízes. Jose Luiz Bolzan de Morais e Flaviane de Magalhães Barros coordenadores. Arraes, 2014, p. 147.
} 
The legal discretion or the open character norms provide this. In order to measure the degree of legal activism is not necessary to analyze the merit of the question, but identify the possibility of using power by the judge. So, if this is the case, we live in high activism degree.

In many cases of great possibility to interpret, there are thesis, which are completely different, however, any of them are wrong or out of the legal system.

Judge with principles or with open clauses allows this freedom, as already affirmed: good freedom and needed, but dangerous. The process can be a clear strategy of power, so, it can have clear rationality a posteriori to support specific purposes, without, however, being identified. There is an important crisis, which is the object of the study. We verified that it is possible to defend the quote system in universities, for example, with the principle of equality and also criticize this system with the principle of equality.

We investigated in some specific cases the State has understood this maneuver and does it, this means, it tries to get a rationality a posteriori to certain purposes. It is however, a dangerous, which needs to be studied.

In the current scenery, the degree of interpretation of the pretension to be judged is high, the power verifies this because it is diffuse; it will appropriate and (already appropriates) and this maneuver is dangerous.

Mutatis mutandis, we will highlight the cases study. In the concentre score (REsp. 1419.697) there is not too many proof with expressed favoritism of a specific economical group, the question is punctual, although it favors the strong part of the procedural relation. The Special Resource, which represents the controversy, was the REsp 1.419.697. It was understood by the scoring system lawfulness and even the minister Sanseverino, explained that some companies work for the scoring system do not have the duty to reveal the formula of the calculations or mathematical method they used. However, they should inform to the holder of the data score used for that value was reached in the risky evaluation of credit.

The losses of the savings accounts do not contribute to the final decision, but the discussions are carried out most of the time by economical questions, this means that a rationality a posteriori is looked for. The rationality a posteriori: of consumers, to punish the banks and, by the banks in order not to have big economic damages for Brazil due to some high given values.

Febraban (Brazilian Bank Federation) adopts the projection done by the Central Bank has an estimative of 150 billion of values involved in the actions. Idec (Consumer Defense Institute) estimates 8,4 billion because it excludes 81,2 billion referring to Collor Plan 1. 
In an interview, Antonio Delfim Netto, former minister of Reuters (Uol Economy) said that the pressure of the government on the STF can be counterproductive and make the other ministers to decide against the government. He thinks that the STF is trying to show some independence in relation to the Executive Power, and could decide in favour of the correction, independently of the eventual economic developments of the decision

The instrumentality a priori was not enough to solve the theme studied here, it necessary though, to have the argument of rationality $a$ posteriori of the judge, involving economic issues by the economy of the country.

In Funrural, the same discussion, without decision, so some discussions about excessive values and their reflexes. Through the Extraordinary Resource $n^{0}$ 363.852, the STF judged the exigency of contribution to be unconstitutional to individuals of Funrural, determined by the article $1^{\circ}$, of the Law $n^{0} 8.540 / 92$, which changed the Law $n^{0} 8.212 / 91$. The foundation of unconstitutionality was the charging institution through the ordinary Law and not complementary. It is estimated that the defeat can cost R\$ 13 billion to the public safes, this bearing in mind just the last five years.

The National Treasury Attorney that, with the end of Funrural, about RS 2,5 billion a year will be collected by the public safes. To the assistant attorney, Fabricio de Soller, the decision of the Supreme will increase the evasion in the rural area. It will be an huge impact in the security social budged in five to on, this means, for each real collected, five will be spent with the system beneficiaries, he says (JUSBRAZIL) .

Considering everything already exposed about the case, we will now analyze if there is a strategy of power or instrumentality in the decision bearing in mind what is available in the site of the published decisions. In the Extraordinary Resource number 596.177/RS we have as a rapporteur, the minister Ricardo Lewandowiski, who recognized the general repercussion of the matter and other foundations, highlighted that "the economic repercussion is evident so, the solution of the case can imply a relevant impact in the security social budget and of the tributes contributors"

The procedural process of the resource still contemplates the order of modulation of the effects only to the future by the Union Side. The Minister Marco Aurélio chose the unconstitutionality because only the Constitution is exhausting considering the facts that can cause the financing obligation of the social security. The Minister Cármen Lúcia voted against the order of modulation of the effects and said that there is no exceptional social interest and that the Plenary has been extremely strict about the effect modulation when the contributor is mentioned, making it necessary to adopt the a similar criteria when we talk about revenue. 
We conclude that with the reading of the decisions about the case, there was not a rationality a posteriori or legal foundations based on economic aspects having in mind the high values involved. The judgment was guided almost totally in formal themes.

In the Usineiros, there is clear rationality a posteriori. There is a precedent change previously known, there is also a wide power for the judgment, specifically for change of opinion without being incoherent to the legal system. In 2013 the STJ judged a repetitive recourse (REsp 1.347.136) about the theme and confirmed its jurisprudence. It recognized that the government must refund the ethanol factories. However, they empty their own decision, because they obliged the factory men to prove the damages they had with the tabulation.

Up to that moment, there were more than 40 judges in favour to the refunds in STJ and other 30 in the STF. This sudden change illustrates what the Minister Humbert Gomes the Barros already affirmed in his vote in the AgRg in the Special Recourse 382.736, that in the last few years, we have demonstrated a deep and constant insecurity, and continues saying that STJ figures it as "banana boat pilot" which tries to defeat the constitution guarantees $^{1}$

Programme more doctors. Here we verified instrumentality $a$ priori through a provisory measure (PM 621/2013) and rationality $a$ posteriori to keep its legitimacy. In 2013, for example, the TRF of the $5^{\text {th }}$ Region did not accept the suspension order of the injunction allowed by the Federal Justice of Ceará (FJCE), that absolves the Medical Regional Council of ${ }^{88}$ that State (CRM-CE) of promoting the provisory register of the exchange doctors to join the More Doctors Project in. Brazil

The economic worry through an instrumentally a priori in the elaboration of the Law 8.437 of 1992 is clear when it allows in its article $4^{\circ}$,

1 AgRg in Special Recourse 382.736. “ We are conductors, and me - Minister of one Court whose decisions, the Ministers themselves do not respect - I feel sad. As a contributor, I am, I go deep into insecurity, with a passenger of that tragical fight in which the pilot got lost in the middle of the night above Amazon Forest: he turned left, folded to the right and the passengers without knowing anything, until suddenly they discover that they were lost: The plane with the STJ is extremely lost. Now, we are about to see again a precedent which we fixed years of a trimester. Now we say that it is wrong because somebody gave us a lesson saying that this precedent should not have been done like that. In the tourist beaches, around the world, there is a toy, which an enormous float, full of people is dragged by a yacht. The function of the pilot of its yacht is to drop people out of the float. So, the yacht goes straight and suddenly, it makes $90^{\circ}$ degrees curves. The game only finishes when all of us, the passengers of the boat are in the sea. So, the STJ seems to have assumed the role of the pilot of that yacht. Our role has been to beat the constitution guarantees. Available in: ww.stj.jus.br/portal/site/STJ. Accessed in: 17 nov. 2014. Free Portuguese translation. 
the possibility of suspending the injunction to avoid a great damage to the order, health, security and public economy.

The vote of Minister Barroso in the process of the non-retirement (RE 661.256) is one of the biggest examples of rationality a posteriori with economical purposes and clear manifestation of power, and also, the legal activism. Barroso admitted a forth copy considering it fairer, even though he recognized that he could be invading the Congress Laws. For the minister the act of non-retirement must be permitted without the devolution of received values, and with the calculation of the welfare factor, which considers the age and salary with the date of the first retirement.

In his conclusion (STF, RExt 661.256), the Minister points out that he tried to produce a balanced solution between the secured laws and the legitimate fiscal interests. He recognized that the decision is certainly innovative

In the case of the Precátorios ( Constitutional amendment $n^{o}$ 62/2009), there is a manifest rationality a posteriori in the decision that even though they consider unconstitutional, the system determines the continuity of what was considered unconstitutional.

In the primary surplus, there is clear instrumentality a priori. The Law project converted in Law (Law $n^{0}$ 13.053) authorized, therefore, the government to not to obey the goal of the economy to the interest payment of the public debts of 2014. The goal was around R\$ 81 billion, but actually, the government was authorized to finish the year in debt. It is the instrumentality a priori to avoid the supposed crime of fiscal responsibility. They are two, however, the ways to reach the power, or the instrumentality a priori, or the rationality a posteriori. With the good fame of the Law ${ }^{1}$ and the legitimacy characteristic, really useful, the solution is through instrumentality a priori because as a proved project of Law, theoretically it is legal. Finally, in the process that judged the Mensalação (Penal Action AP470 STF), Minister Joaquim Barbosa speech, after the discussion with Minister Luis Roberto Barros, clears that the punishments by the conspiracy in the judgment of Mensalão were calculated to avoid the prescription. According to Joaquim Barbosa: It was done for that, come on! There is not another great example of rationality a posteriori.

\section{Conclusion}

In this scenery, the inevitable questioning about what justice is, appeared in the studies. If there is a historical evolution demonstrating that not always what we lived in the present is synonym of justice, that there is a clear connection between the Law and power, that the Law has clear connection with the economy and the Legal system is protagonist, which is the meaning of justice? 
It is verified since the beginning that we are not worried with metaphysic considerations, but we are worried in discussing about justice in the more practical plan because democracy is not synonym of consensus having in mind the protection of the fundamental Laws and diversity. To sum up, what is possible to conclude? Or better yet, in a pragmatic vision, with this reality, how is it possible to be fair or search for justice?

What motivates the world are not the answers, but the questions. Jostein Gaarder (1997), in “Hey! Is there anybody there?” used to say that a good question is worthy reverence. We do not aim a reverence, far from that, but the pretension of the study is to question because an answer for what is justice we do not have, so as this is one question which is probably done by all humanity since its existence.

Justice is not found in classical positivist system nor in a system without minimum formalities. The formality is needed and a pillar to any process. The Law will not predict all the situations (impossible), so in this way, the use of principles and the existing values is necessary in society. The judge has to use the discretionary power but not in an unrestricted way, always with limits that are carefully established by the legal system (then, the needs of formalities).

Although certain caution is necessary about the power, because its diffuse, it can assume temporally some hierarchy, this means that I can be determined, interested and can have a high degree in the hierarchy of power and, so conduct certain changes for its interest ( both in the instrumentality $a$ priori and in the rationality a posteriori). Then, a legal system that does not control or tries to control these forces will not be fair.

The ideological process of the context here must wisely be analyzed because the ideological thought, without altering the reality, alters the comprehension and consequently, the meaning.

The economy certainly can provide great contribution to justice. The economy worries with real people, observing to be difficult to believe that real people could be totally indifferent to the question made by Socrates: "How should we live?"

The instrumentality a priori must also be glimpsed in an economical vision, like the rationality a posteriori. There is a scarcity of the natural resources, human or technical, but what misses is the previously determined Laws and the ones created to fulfill these purposes.

Logically, there is difficulty in determining which are those purposes, religious, economical, of great groups, of the majorities, of the minorities, but Amarttya Sen still points out the economy can become more productive if it gives more attention and more explicit to the ethical considerations which adapt to the behavior and human judgment. 
However, we highlight a special attention in contemporary world to the ethical foundations to explain the justice. The ethical foundations are not a secure rock to throw and contemplate all the justice principles, the danger is to define which ethical content this is going to be as we have already mentioned.

The process is needed in any legal system, which discusses the justice, the instrumentality a priori. The law, on the one hand, does not follow all the alterations of a society during its evolution, being also necessary in some cases, the rationality a posteriori.

O processo se faz necessário em qualquer sistema legal que discuta justiça, a instrumentalidade a priori também. A lei, por sua vez, não acompanha todas as alterações de uma sociedade no decorrer da sua evolução, sendo necessário também em determinados casos a racionalidade $a$ posteriori.

The instrumentality a priori and the rationality a posteriori when used to fair purposes, they are necessary in our point of view of extreme importance. The difficulty is found when they are used as power strategies. Even when they are used to economical purposes, it seems that in some cases, they have a connection with justice, but it is undeniable that determine which economical purpose, they are going to follow, it is a hard task.

\section{References:}

ARENDT, Hannah. Responsabilidade e julgamento. Edição Jerome Kohn. Revisão técnica Bethânia Assy e André Duarte. Tradução Rosaura Einchenberg. São Paulo: Companhia das Letras, 2004.

. A condição humana. 11. ed. Tradução: Roberto Raposo. Revisão técnica: Adriano Correia. Rio de Janeiro: Forense Universitária, 2010.

DWORKIN, Ronald. Levando os direitos a sério. 3. ed. Tradução: Nelson Boeira. São Paulo: Martins Fontes, 2010. (Biblioteca Jurídica) . Taking Rights Seriously. Cambridge, Massachusetts:

Havard University Press, 1977/1978.

GUERRA FILHO, Willis Santiago. Teoria política do direito: a expansão política do direito. Willis Santiago Guerra Filho, Henrique Garbellini Carnio. 2 ed., rev., atual. e ampliada. São Paulo/; Editora Revista dos Tribunais, 2013.

GAARDER, Jostein. Ei! Tem Alguém ai? São Paulo. Companhia das Letrinhas, 1997.

GRAU, Eros Roberto. A ordem econômica na constituição de $1988.16^{\circ}$ ed. Revista atualizada. Editora Malheiros, 2014.

. O direito posto e o direito pressuposto. $8^{\mathrm{a}}$ ed. revista e ampliada. Editora Malheiros, 2011. 
GODOY, Arnaldo Sampaio de Moraes. Direito e economia: introdução ao movimento law and economics. Disponível em: planalto.gov. br/ccivil_03/revista/rev_73/artigos/artigos.htm. Acesso em: 22 set. 2014 JUS BRASIL. STF põe fim à cobrança do Funrural Disponível en: http://abdir.jusbrasil.com.br/noticias/2076660/stf-poe-fim-a-cobranca-dofunrural. Acesso em: 18 mar. de 2015.

FARIA, José Eduardo. O direito na economia globalizada. Malheiros Editores Ltda. 2004.

desenvolvimento e justiça: direito em debate. São Paulo: Saraiva, 2011

. Direito e economia na democratização brasileira. São

Paulo: Saraiva, 2013. (Coleção direito, desenvolvimento e justiça / coordenada por José Rodrigo Rodriguez).

FARIA, Gustavo de Castro. Jurisprudencialização do direito: reflexões no contexto da processualidade democrática. Belo Horizonte: Arraes Editores, 2012.

FOUCAULT, Michel. História da sexualidade I: A vontade de saber. Tradução de Maria Thereza da Costa Albuquerquer e J. A. Guilhon Alburqueque. 1 ed.. São Paulo, Paz e Terra, 2014. Do original Francês: Histoire de la Sexualité I: La volonté de savoir.

Terra, 2014a.

. Microfísica do Poder. 28 ed. Rio de Janeiro: Paz e

. Ditos e escritos, volume IV: estratégia, poder-saber.

Organização, seleção de textos e revisão técnica Manoel Barros da Motta; tradução Vera Lucia Avellar Ribeiro. 3 ed. Rio de Janeiro: Forense Universitária, 2012.

- Vigiar e punir: nascimento da prisão; tradução de Raquel Ramalhete. 41, ed. Petrópolis, RJ: Vozes, 2013. . A ordem do discurso. São Paulo: Loyola, 1996 . A verdade e as formas jurídicas. Tradução Roberto Cabral de Melo Machado e Eduardo Jardim Morais, supervisão final do texto Léa Porto de Abreu Novaes... et al J. Rio de Janeiro: Nau Ed. 1999.

FUGA, Bruno Augusto Sampaio; CENCI, Elve Miguel. Direito Contemporâneo - Perspectivas. Artigo Direito e Discricionariedade. A discricionariedade do Juiz: discussão entre Dworkin e Hart. Bruno Augusto Sampaio Fuga e Elve Miguel Cenci. Editora CRV, 2013:47/75.

IORIO FILHO, Rafael Mario e DUARTE, Fernanda. O Supremo Tribunal Federal e o processo como estratégia de poder: uma pauta de análise. R. SJTJ, Rio de Janeiro, n. 19, 2007.

LASSALLE, Ferdinand. Que é Uma Constituição? Edições e Publicações Brasil, São Paulo, Tradução: Walter Stönner, 1933. 
HART, Herbert Lionel Adolphus. The Concept of Law. 2. ed. Oxford University Press. 1997.

O conceito de direito. Organizado por Penelope A. Bulloch e Joseph Raz. Tradução de Antonio de Oliveira SetteCâmara. Revisão de tradução: Marcelo Brandão Cipolla. Revisão técnica Luiz Vergílio Dalla-Rossa. São Paulo: Martins Fontes, 2009. (Biblioteca Jurídica WMF).

NERY Junior, Nelson. Princípios do processo na Constituição Federal. 10ª ed. São Paulo: Editora Revista dos Tribunais, 2010.

NUNES, Dierle. Direito Jurisprudencial. Precedentes, Padronização decisória preventiva e coletivização. Teresa Arruda Alvim Wambier coordenação. São Paulo. Editora Revista do Tribunais, 2012, p. 245 a 276.

- Acesso à justiça democrático. Dierle Nunes, Ludmila Teixeira. 1. ed. Brasília, DF: Gazeta Jurídica, 2013.

PALMA, Rodrigo Freitas. História do Direito. 4 ed. São Paulo: Saraiva, 2011.

REALE, Miguel. Pluralismo e liberdade. 2. ed. Rio de Janeiro. Expressão e Cultura. 1998.

SEN, Amartya Humar, 1999. Sobre ética e economia. Tradução Laura Teixeira Motta; revisão técnica Ricardo Doninelli Mendes. $1^{\circ}$ ed. São Paulo: Companhia das Letras, 1999.

. A ideia de justiça. Tradução Denise Bottmann,

Ricardo Doninelli Mendes. São Paulo: Companhia das Letras, 2011.

SOUZA, Nali de Jesus de. Economia básica. 1. ed. 8 reimpr. São Paulo: Atlas, 2014.

STRECK, Lenio Luiz. O que é isto - decido conforme minha consciência? 3 ed. Porto Alegre: Livraria do Advogado Editora. 2012.

- Verdade e Consenso : constituição, hermenêutica e teorias discursivas. 4 ed. São Paulo : Saraiva, 2011.

. O ativismo e a judicialização: De como os números

podem velar o fenômeno. In Novo Constitucionalismo Latino - Americano. O debate sobre novos sistemas de justiça, ativismo judicial e formação de juízes. Jose Luiz Bolzan de Morais e Flaviane de Magalhães Barros coordenadores. Arraes, 2014, p. 144 a 155.

WATANABE, Kazuo. Cognição no processo civil. $4^{\mathrm{a}}$ ed. São Paulo: Saraiva, 2012.

UOL ECONOMIA. Pressão do governo no STF sobre poupança pode ser tiro no pé, diz Delfim. Disponível em: http://economia.uol.com.br/. Acesso em: 21 de nov. 2014 